\title{
Identifying and prioritizing requirements for an e- platform to strengthen nursing in Kazakhstan A two- step research design including a literature review and a Delphi study
}

\author{
Bea Dijkman ( $\sim$ b.l.dijkman@pl.hanze.nl ) \\ Hanzehogeschool Groningen \\ Alberta Oosterhoff \\ Hanzehogeschool Groningen \\ Amangali Akanov \\ Astana medical university \\ Wolter Paans \\ Hanzehogeschool Groningen
}

\section{Research article}

Keywords: Nursing, e-platform, requirements analysis, knowledge sharing, collaboration, nursing education, nursing science, nursing practice, Kazakhstan

Posted Date: January 15th, 2020

DOI: https://doi.org/10.21203/rs.2.20955/v1

License: (1) (1) This work is licensed under a Creative Commons Attribution 4.0 International License. Read Full License 


\section{Abstract}

\section{BACKGROUND}

This paper addresses the requirements for an e-platform that is to be developed to strengthen nursing in Kazakhstan. It aims to support knowledge sharing and collaboration in nursing education, research, and clinical practice. To construct the platform, a requirement analysis was conducted in a two-step design that included a literature review and a Delphi study. The aim of the review was to identify requirements for an eplatform for collaborative developments in nursing science and nursing research education. The aim of the Delphi study was to specifically prioritize these requirements for Kazakhstan.

\section{METHODS}

A literature search was accomplished using different electronic databases between February and April 2018 by applying search terms concerning nursing, e-platform, research, and education. Included studies should not be older than six years, written in English or Russian, involve nurses or nursing students, and address learning by e-platform. The Delphi study included two rounds of questionnaires containing input from the review and from other project activities. Rating occurred among a panel of experts from Kazakhstan, Finland, and the Netherlands. Outcomes were analysed applying content validity ratios and level of consensus thresholds.

\section{RESULTS}

The literature search generated eight studies. Data extraction and synthesis resulted in nine categories of requirements covered by four groups in the Delphi study. One group contains content-related requirements encompassing aim and users, platform structure, educational content, and nursing skills. Another group comprises functional requirements including communication, knowledge acquisition, and management. A third group refers to usability requirements, and the fourth group contains technical requirements. The Delphi study generated a list of 52 essential requirements and 15 useful requirements with a high level of consensus.

\section{CONCLUSION}

The input for the Delphi corresponded with the perceptions of experts concerning the needs of the eplatform to be developed. The list of requirements is well-embedded in the literature as well as in the national context of nursing in Kazakhstan and, therefore, will contribute to improving the trinity of nursing education, research, and practice. Although the list is context-specific, when validated by a panel of experts, it is considered to be applicable universally when developing e-platforms for nursing.

\section{Background}

\section{E-platforms for collaboration and education in nursing}


Information and communication technology (ICT) is changing rapidly, and there are many different eplatforms to support online learning and collaboration. In the field of nursing, the use of e-platforms and other ICT applications is also increasing. ICT affords opportunities to meet and network virtually and to provide the ability for collaboration among persons with similar professional interests [1]. These shared interests may involve nursing education and clinical practice along with scientific research initiatives. It has become common practice that nursing educational institutes, nursing research institutes, and various clinical nursing associations use the Internet, social media, and e-platforms. Collaboration and knowledge exchange within these three domains of nursing, the so-called trinity of nursing education, research, and practice, is considered to be important for evidence-based quality improvement and healthcare transformation [2].

First, in nursing education, the use of e-platforms has become widespread in many countries. E-platforms that are used for educational purposes generally include interactive online services that provide trainers, learners, and others involved in education with information, tools, and resources to support and enhance education delivery and management [3]. To support learning processes, interaction, and collaboration of learners and educators in the cognition, construction, and socialization process of learning, the e-platform combines the advantages of learning management systems with social software [4].

Second, in nursing research, the number of collaborative nursing research projects will increase considerably in the next decade due to developments in ICT and global health. Although geographic proximity is known to facilitate successful collaborations, ICT can enhance distant cooperation as international nursing science collaborations continue to grow [5]. Accordingly, at international and national levels, nursing science dissemination continues to develop and is facilitated by developments in ICT that enhance distant collaborations and knowledge sharing. Devices such as smartphones are employed for the provision of information to increase nurses' awareness concerning the importance of research and the presentation and accessibility of research evidence [6, 7]. The use of ICT has become increasingly important for informing and educating nurses about research findings, evidence-based practice (EBP), and clinical guidelines.

In addition, in nursing practice, literature shows evidence that nurses have increased access to ICT for retrieving information that is related to EBP evidence-based practice. Nurses are able to search healthrelated websites and health databases to expand their knowledge, improve their clinical judgement, and consequently enhance the quality of care [8]. Social media applications that have been developed as teaching tools to increase knowledge and skill levels of health care professionals are also used by nurses in practice. Several studies report positive outcomes in establishing mentoring relationships, building best practices by teaching through social media, and supporting nurses in maintaining currency in clinical practice $[9,10]$.

Considering this, the development of e-platforms will support knowledge sharing and collaboration in the trinity of nursing education, nursing research, and nursing practice on both national and international levels thus generating improvement in the quality of nursing.

\section{Challenges in nursing and nursing education in Kazakhstan}


As one of the countries in the Central-Asian region that gained independence in 1991, Kazakhstan has undertaken major efforts to reform its post-Soviet healthcare system [11]. Still, increasing healthcare utilization and improving health outcomes are among the most challenging aspects of healthcare in that country [12]. In alignment with the changes in healthcare, the role and value of nursing care professionals as well as their organizational authority and responsibility for work results are essentially increasing [13]. The developments in healthcare and changes for nurses have a considerable impact on nursing education. Consequently, Kazakhstan is facing widespread changes in nursing higher education.

The project "Promoting the Innovation Capacity of Higher Education in Nursing During Health Services' Transition" (ProlnCa) has been initiated to support innovations and the transition process in nursing education and nursing research [14]. This European-funded project is operating from 2017-2020 and is supported by four European Higher Educational Institutes (HEls) - two in Finland, one in the Netherlands, and one in Slovenia - that work cohesively with Kazakh HEls and associated partners including, among others, the Ministry of Healthcare, the Ministry of Education, medical colleges, and health care organizations. A variety of ProlnCa project activities, such as master classes for Kazakh participants along with exchanging international best practices, accelerates the development that is required for the reforms that are in progress in Kazakhstan. Improving the collaborative structures of the trinity of nursing education, research, and clinical practice are the core of the innovation capacity that is needed to realize the transition process [14]. To guarantee the continuation of the transition process after the project is completed in 2020, communities of professional nurses, nursing educators, researchers, and students should be encouraged to exchange their involvement and activities. For this reason, an e-platform will be developed to support knowledge sharing and collaboration and provide contemporary evidence-based knowledge available for all nurses, nursing students, and nurse educators [14].

\section{Development of the e-platform}

To consolidate the content, functioning, and further development of the e-platform, its administration, technical support, management, and control is managed by the Center of Nursing Excellence (CNE) in Kazakhstan. This center, developed during the ProlnCa project period, aims to ensure a long-term impact with sustainable mechanisms for collaboration and knowledge sharing. Therefore, the CNE actively collects, promotes, and shares evidence-based nursing clinical guidelines and educational materials for nursing and nursing research. The e-platform will support the knowledge sharing and collaboration and include online courses about nursing research, evidence-based nursing, nursing clinical guidelines, and nursing leadership.

Since the e-platform aims to contribute to the Kazakh healthcare transition process, it is important that it meets the needs and requirements of the stakeholders who will be the future users. For this, stakeholders from the fields of nursing education, nursing practice, and nursing research should be consulted to ensure that platform users' needs are being fulfilled. Therefore, a requirements analysis was conducted in a twostep method that included a literature review proceeded by a Delphi study. The results of this combined study will contribute to identifying and prioritizing the essential requirements when developing the eplatform to strengthen nursing in Kazakhstan. 


\section{Methods}

\section{Study design}

This combined study is characterized by a two-step design that includes a literature review and a Delphi study. The literature study aimed at providing insight into the generally perceived requirements of an eplatform for collaborative developments in nursing science and nursing research education. Additional requirements for the e-platform that are specific for the Kazakh situation were derived from the ProlnCa project activities. The findings of the literature review along with contributions from the participants of ProlnCa project activities are the input for the Delphi study which aims to achieve consensus among experts on prioritizing these requirements.

\section{Methods literature review}

A literature review was conducted in international collaboration with researchers from the Netherlands, Kazakhstan, and Finland. Consensus on search strategy and screening as well as the selection of results was achieved in online and face-to-face meetings.

A series of search terms was determined concerning e-platform or online environment, nursing, research or evidence, and education or learning. From these search terms, different search strings were developed to browse in a variety of electronic databases such as IEEE, TRIP, EBSCO, ABI, PubMed, and CINAHL. These different searches were conducted between 10 February and 12 April 2018 and are presented in Table 1. In addition to this systematic approach, literature introduced in the included studies was also examined, also known as the snowball technique, to minimize the possibility of overlooking important studies using the search strategy.

Table 1: Search terms

\begin{tabular}{|ll|}
\hline $\begin{array}{l}\text { Electronic } \\
\text { database }\end{array}$ & Search terms \\
\hline IEEE & e platform AND nursing AND research AND education \\
\hline Trip & e-platform AND nursing AND research AND practice \\
\hline EBSCO & (eplatform OR portal) AND "nursing education" \\
\hline ABI & (eplatform OR portal) AND (healthcare OR nursing) \\
\hline PubMed & $\begin{array}{l}\text { ("evidence-based nursing" (MeSH) OR nursing) AND ("computer communication } \\
\text { networks" (MeSH) OR "virtual learning environment") }\end{array}$ \\
CINAHL & $\begin{array}{l}\text { (nursing OR nurses) AND (research OR evidence-based) AND (education OR learning) } \\
\text { AND (online OR internet) }\end{array}$ \\
\hline
\end{tabular}




\section{Inclusion criteria}

Studies should involve humans, be published in peer-reviewed academic journals, not older than six years, and written in the English or Russian language. Further inclusion criteria were that studies should concern nursing students or clinical nurses who had participated in an online platform or learning programme concerning research or evidence-based nursing. The efficacy or impact of the online platform or programme should have been evaluated by an intervention using an evaluation instrument, or the platform's development process had been evaluated. The students' perceptions, experiences, or opinions should be an element of the evaluation. Studies published in reviews and meta-analyses could be subject for consideration as well.

The evidence level of included studies was graded according to the Oxford Centre for Evidence-based Medicine [15]. The methodological quality appraisal was conducted according to the Joanna Briggs Institute checklists [16].

\section{Methods Delphi study}

The Delphi method is a consensus-building tool that has been applied in a variety of fields, including innovations in health care [17]. Since the method addresses non-interactive groups, it is possible to draw upon experts who are based at considerable geographic distances, as was the case in this study.

\section{Panel of responding experts}

A panel of experts was established including 59 respondents originating from Kazakhstan, Finland, and the Netherlands. Since the e-platform should correspond with the needs concerning Kazakh nursing developments, most experts (75\%) were from Kazakhstan. Experts in the field of education, research, clinical practice, and information technology as well as professional leadership and the government were included. These experts were either participants in the ProlnCa project activities or connected to the project as associated partners or international project members. The inclusion criteria for experts were that they should be professionally related to the field of nursing and have adequate understanding or experience in at least one of the following four domains: nursing education on vocational, bachelor, or master level, nursing research, digital knowledge sources in the field of nursing, or digital knowledge sources in the field of online collaboration. Project members that were directly engaged in developing the e-platform were excluded since they would be too closely involved.

\section{Questionnaires}

The Delphi study included two rounds of questionnaires and contains statements concerning e-platform requirements. For the first round, a list of 62 statements was composed based on the requirements resulting from the literature review and the input from other ProlnCa project activities. These statements were clustered according to four groups: 'content requirements', 'functional requirements', 'usability requirements' and 'technical requirements'. The group 'content requirements' also included nursing content. For prioritizing nursing content issues, the seven domains of the Nursing Intervention Classification (NIC) 
were used, which are: Physiological basic, Physiological complex, Behaviour, Safety, Family, Community, and Health System [18].

The first questionnaire was transferred to the SurveyMonkey tool in order to electronically aggregate the survey data [19]. Respondents received a link to the questionnaire by e-mail and were requested to provide informed consent. They were subsequently invited to rate the level of importance of each of the requirements on a 3-point scale: 1) essential, 2) useful but not essential, or 3) not necessary [20] Rating was based on the responding experts' own opinions and anonymity was guaranteed. In addition, two openended questions were included by which respondents could contribute additional requirements. A reminder was sent after two weeks and a second reminder after four weeks.

The questionnaire for the second round was composed based on the results of the first round. All of the requirements were again presented / with some minor linguistic modifications and five additional statements based on the analysis of the open-ended questions in the first round. In the second questionnaire, requirements could be rated as: 1) essential or 2) useful but not essential. As suggested by Linstone and Turoff [21] the Delphi procedure enables individual experts to provide feedback on the results of the first round with the opportunity to modify their opinions [21]. Therefore, they were invited to agree or to disagree with the list of 'essential' and the list of 'useful but not essential' requirements.

Both questionnaires were in the English and Russian languages. Anonymity for individual responses was guaranteed. [21]

\section{Analysis}

For the analysis of the ratings in the first round, the content validity ratio (cvr) was applied, which is the appropriate technique for determining consensus among a panel of experts. [20] The crr should be determined as $\left(n_{e}-N / 2\right) /(N / 2)$ in which $n_{e}$ is the number of panellists indicating 'essential', and $N$ is the total number of panellists. In a panel of 40 or more experts, a content validity ratio of 0,29 is regarded as the minimum. [20]

The outcomes of the second round in which requirements could be rated as 'essential' or 'useful but not essential' were analysed by allocating percentages. Consensus among experts had been determined by applying a threshold of $75 \%$, which is the appropriate analysis technique in this type of Delphi study. [22]

\section{Results}

\section{Results literature review}

After removing duplicates and studies that did not meet the inclusion criteria, a further selection was accomplished. This selection included the availability of full-text and screening based on title and abstract. Additional consideration of inclusion criteria, among which was achieving diversity in the country of origin of the studies, resulted in six relevant studies. After reading these six studies' full-text, the researchers determined that references to two studies were not initially included by the first queries but seemed relevant 


\section{Included studies, country and study participants, design, level of evidence and methodological quality appraisal}

Included studies are presented in Table 2. Study participants were nurses or nursing students from Canada, China, Spain, Turkey, Singapore, the United States, Portugal, and Brazil. Three of the included studies had a cross-sectional design, two were qualitative in nature, two pre-post studies were included, and one study was a systematic review of randomized controlled trials. The evidence level was graded according to the Oxford centre for evidence-based medicine. The methodological quality appraisal was graded according to the Joanna Briggs Institute checklists. The methodological quality of all of the included studies was good to excellent. In one cross-sectional study, excellence was achieved since confounding factors were addressed. Excellence was also achieved in one qualitative study by addressing the researchers' roles and possible influence of study results. 
Table 2

Included studies, country and study participants, study design, evidence grade, and methodological quality appraisal score

\begin{tabular}{|c|c|c|c|c|}
\hline Included study & $\begin{array}{l}\text { Country and } \\
\text { study } \\
\text { participants }\end{array}$ & $\begin{array}{l}\text { Study } \\
\text { design }\end{array}$ & $\begin{array}{l}\text { Evidence } \\
\text { grade }^{*}\end{array}$ & $\begin{array}{l}\text { Methodological } \\
\text { quality } \\
\text { appraisal } \\
\text { score }^{* *}\end{array}$ \\
\hline $\begin{array}{l}\text { Davidson, SJ. et al. Teaching EBP } \\
\text { Using Game-Based Learning: } \\
\text { Improving the Student Experience. } \\
\text { Worldviews on Evidence-Based } \\
\text { Nursing, 2016, 13:4, 285-293. }\end{array}$ & $\begin{array}{l}\text { Canada } \\
\text { Undergraduate } \\
\text { nursing } \\
\text { students } \\
\mathrm{n}=30\end{array}$ & $\begin{array}{l}\text { Cross- } \\
\text { sectional } \\
\text { Study }\end{array}$ & B & 6/8 (Good) \\
\hline $\begin{array}{l}\text { Du, S. et al. Web-based distance } \\
\text { learning for nurse education: a } \\
\text { systematic review. International } \\
\text { Nursing Review, 2013, 60, 167-177. }\end{array}$ & $\begin{array}{l}\text { China } \\
9 \text { RCT's } \\
\text { Nursing } \\
\text { students and } \\
\text { employed } \\
\text { students }\end{array}$ & $\begin{array}{l}\text { Systematic } \\
\text { Review of } \\
\text { RCTs }\end{array}$ & $A$ & 10/11 (Good) \\
\hline $\begin{array}{l}\text { Gagnon, J. et al. Adaptation and } \\
\text { Evaluation of Online Self-learning } \\
\text { Modules to Teach Critical Appraisal } \\
\text { and Evidence-Based Practice in } \\
\text { nursing. Computers, Informatics, } \\
\text { Nursing, 2015, 7, 285-294. }\end{array}$ & $\begin{array}{l}\text { Canada \& } \\
\text { Spain } \\
\text { Clinical nurses } \\
\mathrm{n}=83 \\
\text { Quebec (36) } \\
\text { and Basque } \\
\text { country (47) }\end{array}$ & $\begin{array}{l}\text { Pre-post } \\
\text { study }\end{array}$ & B & $8 / 9$ (Good) \\
\hline $\begin{array}{l}\text { Karaman, S. et al. Evaluation of an } \\
\text { online continuing education program } \\
\text { from the perspective of new graduate } \\
\text { nurses. Nurse Education Today, 2014, } \\
34,836-841 \text {. }\end{array}$ & $\begin{array}{l}\text { Turkey } \\
\text { Registered } \\
\text { nurses } \\
n=2365\end{array}$ & $\begin{array}{l}\text { Cross- } \\
\text { sectional } \\
\text { Study }\end{array}$ & B & 6/8 (Good) \\
\hline $\begin{array}{l}\text { Kowitlawakul, Y. et al. Development of } \\
\text { an e-Learning Research Module Using } \\
\text { Multimedia Instruction Approach. } \\
\text { Computers, Informatics, Nursing, 2017, } \\
\text { 3, 158-166. }\end{array}$ & $\begin{array}{l}\text { Singapore } \\
\text { Master of } \\
\text { Nursing } \\
\text { students } \\
n=8 \\
\text { ( } 2 \text { focus } \\
\text { groups of } 4 \\
\text { students) } \\
\text { Faculty } \\
\text { members } n=2\end{array}$ & $\begin{array}{l}\text { Qualitative } \\
\text { study }\end{array}$ & $\mathrm{D}$ & 8/10 (Good) \\
\hline $\begin{array}{l}\text { League, K. et al. Increasing Nurses' } \\
\text { Access to Evidence Through a Web- } \\
\text { Based Resource. Journal of Nursing } \\
\text { Administration, 2012, 42:11, 531-535. }\end{array}$ & $\begin{array}{l}\text { United States } \\
\text { Staff nurses } \\
744 \text { pretest } \\
1164 \text { posttest }\end{array}$ & $\begin{array}{l}\text { Pre-post } \\
\text { study }\end{array}$ & B & $8 / 9$ (Good) \\
\hline
\end{tabular}

*Oxford Centre for Evidence-based Medicine, 2018

**Joanna Briggs Institute, 2018 


\begin{tabular}{|c|c|c|c|c|}
\hline Included study & $\begin{array}{l}\text { Country and } \\
\text { study } \\
\text { participants }\end{array}$ & $\begin{array}{l}\text { Study } \\
\text { design }\end{array}$ & $\begin{array}{l}\text { Evidence } \\
\text { grade }^{*}\end{array}$ & $\begin{array}{l}\text { Methodological } \\
\text { quality } \\
\text { appraisal } \\
\text { score** }^{*}\end{array}$ \\
\hline $\begin{array}{l}\text { Mclntyre M. et al. A critical Analysis of } \\
\text { Online Nursing Education: Balancing } \\
\text { Optimistic and Cautionary } \\
\text { Perspectives. Canadian Journal of } \\
\text { Nursing Research, } 2013,45: 1,36-53 \text {. }\end{array}$ & $\begin{array}{l}\text { Canada } \\
30 \\
\text { undergraduate } \\
\text { and graduate } \\
\text { nursing } \\
\text { students }\end{array}$ & $\begin{array}{l}\text { Qualitative } \\
\text { study }\end{array}$ & $\mathrm{D}$ & $\begin{array}{l}10 / 10 \\
\text { (Excellent) }\end{array}$ \\
\hline $\begin{array}{l}\text { Seixas, CA. et al. Usability Assessment } \\
\text { of Moodle by Brazilian and Portuguese } \\
\text { Nursing Students. Computer, } \\
\text { Informatics, Nursing, 2016, 6, 266-271. }\end{array}$ & $\begin{array}{l}\text { Portugal \& } \\
\text { Brazil } \\
\text { Undergraduate } \\
\text { and diploma } \\
\text { nursing } \\
\text { students (79) } \\
\text { Brazilian (53) } \\
\text { and } \\
\text { Portuguese } \\
\text { (26) }\end{array}$ & $\begin{array}{l}\text { Cross- } \\
\text { sectional } \\
\text { Study }\end{array}$ & B & 8/8 (Excellent) \\
\hline \multicolumn{5}{|c|}{ *Oxford Centre for Evidence-based Medicine, 2018} \\
\hline ** Joanna Briggs Institute, 2018 & & & & \\
\hline
\end{tabular}

\section{Included studies, objectives, types of platform, evaluation tools, outcome measures, key findings and recommendations}

In all of the studies, the e-platform users' perceptions and experiences were assessed. The objectives were to evaluate, assess, or discuss either the efficacy and impact or the development of an online platform or programme. The types of platforms that were assessed involved two platforms, one website, and four nursing programmes or courses. One study was a systematic review on a variety of programmes. The evaluation tools were survey questions (Likert scale as well as open ended questions), SDLNRE questionnaire, narratives from focus group discussions and individual face-to-face or telephone interviews, or log records analysis. Outcome measures varied from student engagement, achievement of learning outcomes, nursing skills performance, relevance of contents to website usability, technology, and course usefulness. The objectives, types of platforms or programmes, evaluation tools and outcome measures are presented in Table 3, including the key findings along with the major recommendations. 
Table 3

Included studies, objectives, types of platform, evaluation tools, outcome measures, key findings and recommendations

\begin{tabular}{|c|c|c|c|c|c|}
\hline $\begin{array}{l}\text { Included } \\
\text { studies }\end{array}$ & Objectives & $\begin{array}{l}\text { Types of } \\
\text { platform or } \\
\text { programme }\end{array}$ & $\begin{array}{l}\text { Evaluation } \\
\text { tools }\end{array}$ & $\begin{array}{l}\text { Outcome } \\
\text { measures }\end{array}$ & $\begin{array}{l}\text { Key findings and } \\
\text { recommendations }\end{array}$ \\
\hline $\begin{array}{l}\text { Davidson, SJ. } \\
\text { et al. (2016) }\end{array}$ & $\begin{array}{l}\text { Describe the } \\
\text { development } \\
\text { and } \\
\text { evaluation } \\
\text { of game- } \\
\text { based } \\
\text { learning to } \\
\text { better } \\
\text { prepare } \\
\text { nursing } \\
\text { students to } \\
\text { engage in } \\
\text { EBP }\end{array}$ & $\begin{array}{l}\text { Quest-based } \\
\text { learning } \\
\text { platform (3D } \\
\text { Game Lab) }\end{array}$ & $\begin{array}{l}\text { Survey with } 12 \\
\text { questions } 1-5 \\
\text { pt. Likert scale, } \\
\text { platform } \\
\text { analytics, } \\
\text { thematic } \\
\text { analysis of } \\
\text { students' } \\
\text { comments }\end{array}$ & $\begin{array}{l}\text { Student } \\
\text { satisfaction, } \\
\text { student } \\
\text { engagement, } \\
\text { student } \\
\text { achievement } \\
\text { of learning } \\
\text { outcomes }\end{array}$ & $\begin{array}{l}\text { Provide timely } \\
\text { and } \\
\text { individualized } \\
\text { feedback, create } \\
\text { student choice in } \\
\text { selection of } \\
\text { learning quests, } \\
\text { create } \\
\text { customization of } \\
\text { learning, provide } \\
\text { visible } \\
\text { milestones, level } \\
\text { learning activities } \\
\text { to build on each } \\
\text { other }\end{array}$ \\
\hline
\end{tabular}




\begin{tabular}{|c|c|c|c|c|c|}
\hline $\begin{array}{l}\text { Included } \\
\text { studies }\end{array}$ & Objectives & $\begin{array}{l}\text { Types of } \\
\text { platform or } \\
\text { programme }\end{array}$ & $\begin{array}{l}\text { Evaluation } \\
\text { tools }\end{array}$ & $\begin{array}{l}\text { Outcome } \\
\text { measures }\end{array}$ & $\begin{array}{l}\text { Key findings and } \\
\text { recommendations }\end{array}$ \\
\hline $\begin{array}{l}\text { Du, S. et al. } \\
(2013)\end{array}$ & $\begin{array}{l}\text { Examine the } \\
\text { efficacy of } \\
\text { web-based } \\
\text { distance } \\
\text { education } \\
\text { for nursing } \\
\text { students } \\
\text { and } \\
\text { employed } \\
\text { nurses }\end{array}$ & $\begin{array}{l}\text { Websites } \\
\text { containing } \\
\text { distance } \\
\text { education as } \\
\text { experimental } \\
\text { teaching } \\
\text { strategies }\end{array}$ & $\begin{array}{l}\text { Web-based } \\
\text { distance } \\
\text { nursing } \\
\text { education } \\
\text { compared to } \\
\text { traditional } \\
\text { teaching or } \\
\text { blank control }\end{array}$ & $\begin{array}{l}\text { Knowledge } \\
\text { acquisition, } \\
\text { nursing skill } \\
\text { performance, } \\
\text { satisfaction, } \\
\text { self-efficacy, } \\
\text { cognition, } \\
\text { affection, } \\
\text { interaction }\end{array}$ & $\begin{array}{l}\text { Develop course } \\
\text { information, a } \\
\text { curriculum map, } \\
\text { teaching } \\
\text { materials, } \\
\text { communication } \\
\text { tools, formative } \\
\text { and summative } \\
\text { assessments, } \\
\text { student } \\
\text { management } \\
\text { tools, links to } \\
\text { databases, } \\
\text { teleconferencing, } \\
\text { case-based } \\
\text { learning. Enhance } \\
\text { flexibility, learner } \\
\text { independence, } \\
\text { time efficiency, } \\
\text { content in } \\
\text { text/video/audio } \\
\text { formats, } \\
\text { interactive } \\
\text { designs. Minimize } \\
\text { hardware and } \\
\text { software } \\
\text { problems, } \\
\text { inadequate } \\
\text { information } \\
\text { literacy, dropout } \\
\text { levels, loss of } \\
\text { social process, } \\
\text { inadequate } \\
\text { time/skills to } \\
\text { develop materials, } \\
\text { expenses } \\
\text { involved, lack of } \\
\text { research- } \\
\text { produced proof }\end{array}$ \\
\hline
\end{tabular}




\begin{tabular}{|c|c|c|c|c|c|}
\hline $\begin{array}{l}\text { Included } \\
\text { studies }\end{array}$ & Objectives & $\begin{array}{l}\text { Types of } \\
\text { platform or } \\
\text { programme }\end{array}$ & $\begin{array}{l}\text { Evaluation } \\
\text { tools }\end{array}$ & $\begin{array}{l}\text { Outcome } \\
\text { measures }\end{array}$ & $\begin{array}{l}\text { Key findings and } \\
\text { recommendations }\end{array}$ \\
\hline $\begin{array}{l}\text { Gagnon, J. et } \\
\text { al. (2015) }\end{array}$ & $\begin{array}{l}\text { Evaluate } \\
\text { online self- } \\
\text { learning } \\
\text { modules on } \\
\text { critical } \\
\text { appraisal } \\
\text { skills to } \\
\text { promote the } \\
\text { use of } \\
\text { research in } \\
\text { clinical } \\
\text { practice }\end{array}$ & $\begin{array}{l}\text { Online self- } \\
\text { learning } \\
\text { course } \\
\text { (InfoCritique } \\
\text { Program) }\end{array}$ & $\begin{array}{l}\text { Two } \\
\text { questionnaires } \\
\text { (pre and post } \\
\text { course) } \\
\text { (SDLRNE and } \\
\text { knowledge } \\
\text { questionnaire), } \\
\text { one } \\
\text { satisfaction } \\
\text { questionnaire }\end{array}$ & $\begin{array}{l}\text { Self-directed } \\
\text { learning } \\
\text { readiness } \\
\text { (SDLR), } \\
\text { satisfaction, } \\
\text { knowledge } \\
\text { acquisition, } \\
\text { instructions, } \\
\text { design, } \\
\text { effectiveness, } \\
\text { usability, } \\
\text { course } \\
\text { usefulness }\end{array}$ & $\begin{array}{l}\text { Content } \\
\text { satisfaction } \\
\text { involves difficulty, } \\
\text { number of } \\
\text { examples, } \\
\text { language of } \\
\text { materials, } \\
\text { complexity of } \\
\text { content, number } \\
\text { of modules } \\
\text { addressing } \\
\text { literature } \\
\text { searches, } \\
\text { experimental } \\
\text { designs, and } \\
\text { statistics. } \\
\text { Participation } \\
\text { satisfaction } \\
\text { involves } \\
\text { motivation, } \\
\text { commitment. } \\
\text { Platform } \\
\text { satisfaction } \\
\text { involves user- } \\
\text { friendliness, rapid } \\
\text { load, feedback, } \\
\text { interaction, } \\
\text { structure, easy } \\
\text { navigation. } \\
\text { Prevent lack of } \\
\text { space for } \\
\text { interaction, } \\
\text { enhance transfer } \\
\text { of knowledge into } \\
\text { practice and to } \\
\text { colleagues }\end{array}$ \\
\hline $\begin{array}{l}\text { Karaman, S. } \\
\text { et al. (2014) }\end{array}$ & $\begin{array}{l}\text { Evaluate the } \\
\text { online } \\
\text { continuing } \\
\text { education } \\
\text { program } \\
\text { from the } \\
\text { perspective } \\
\text { of nurses }\end{array}$ & $\begin{array}{l}\text { Online } \\
\text { degree in } \\
\text { nursing } \\
\text { (HELITAM: } \\
\text { first online } \\
\text { bachelor } \\
\text { nursing } \\
\text { program in } \\
\text { Turkey) }\end{array}$ & $\begin{array}{l}\text { Survey with } \\
1-5 \text { pt. Likert } \\
\text { scale, open- } \\
\text { ended } \\
\text { questions }\end{array}$ & $\begin{array}{l}\text { Program and } \\
\text { course } \\
\text { structure, } \\
\text { course } \\
\text { materials, } \\
\text { technology, } \\
\text { support } \\
\text { services, } \\
\text { assessment }\end{array}$ & $\begin{array}{l}\text { Monitor } \\
\text { programme and } \\
\text { course structure, } \\
\text { including quality } \\
\text { of design of } \\
\text { asynchronous } \\
\text { online education, } \\
\text { quality of } \\
\text { effective support, } \\
\text { quality of } \\
\text { technological } \\
\text { infrastructure, } \\
\text { and quality of } \\
\text { teaching }\end{array}$ \\
\hline
\end{tabular}




\begin{tabular}{|c|c|c|c|c|c|}
\hline $\begin{array}{l}\text { Included } \\
\text { studies }\end{array}$ & Objectives & $\begin{array}{l}\text { Types of } \\
\text { platform or } \\
\text { programme }\end{array}$ & $\begin{array}{l}\text { Evaluation } \\
\text { tools }\end{array}$ & $\begin{array}{l}\text { Outcome } \\
\text { measures }\end{array}$ & $\begin{array}{l}\text { Key findings and } \\
\text { recommendations }\end{array}$ \\
\hline $\begin{array}{l}\text { Kowitlawakul, } \\
\text { Y. et al. } \\
(2017)\end{array}$ & $\begin{array}{l}\text { Discuss the } \\
\text { development } \\
\text { and piloting } \\
\text { process, } \\
\text { including the } \\
\text { variety of } \\
\text { evaluation } \\
\text { perspectives }\end{array}$ & $\begin{array}{l}\text { e-learning } \\
\text { research } \\
\text { project } \\
\text { module } \\
\text { using } \\
\text { interactive } \\
\text { multimedia }\end{array}$ & $\begin{array}{l}\text { Two semi- } \\
\text { structured } \\
\text { focus group } \\
\text { sessions, two } \\
\text { individual } \\
\text { interviews }\end{array}$ & $\begin{array}{l}\text { Usefulness, } \\
\text { engagement, } \\
\text { organization, } \\
\text { relevance of } \\
\text { content }\end{array}$ & $\begin{array}{l}\text { Focus on impact } \\
\text { of the e-learning } \\
\text { module on } \\
\text { students' } \\
\text { performance and } \\
\text { students' learning } \\
\text { outcomes }\end{array}$ \\
\hline $\begin{array}{l}\text { League, K. et } \\
\text { al } \\
(2012)\end{array}$ & $\begin{array}{l}\text { Describe the } \\
\text { development } \\
\text { and impact } \\
\text { of a Web- } \\
\text { based tool } \\
\text { to improve } \\
\text { nurses' } \\
\text { access to } \\
\text { evidence }\end{array}$ & $\begin{array}{l}\text { Website } \\
\text { Launched } \\
2009\end{array}$ & $\begin{array}{l}\text { Survey with } \\
1-4 \text { pt. Likert } \\
\text { scale (pretest } \\
2008 \text { and } \\
\text { posttest 2010) }\end{array}$ & $\begin{array}{l}\text { Perceived } \\
\text { access to } \\
\text { EBP, } \\
\text { perceived } \\
\text { ability to use } \\
\text { EBP }\end{array}$ & $\begin{array}{l}\text { Support } \\
\text { increasing use of } \\
\text { EBP, improve } \\
\text { perception of } \\
\text { supervisors' } \\
\text { support for EBP, } \\
\text { allocate time for } \\
\text { staff to use } \\
\text { evidence at work }\end{array}$ \\
\hline $\begin{array}{l}\text { Mclntyre, M. } \\
\text { et al. (2013) }\end{array}$ & $\begin{array}{l}\text { Discuss how } \\
\text { peer } \\
\text { dynamics } \\
\text { influence } \\
\text { student } \\
\text { learning in } \\
\text { an online } \\
\text { environment }\end{array}$ & $\begin{array}{l}\text { Two online } \\
\text { nursing } \\
\text { programs }\end{array}$ & $\begin{array}{l}\text { Individual } \\
\text { face-to-face or } \\
\text { telephone } \\
\text { interviews (N } \\
\text { = 30), one } \\
\text { focus group } \\
\text { interview } \\
\text { (eight } \\
\text { participants), } \\
\text { fieldnotes }\end{array}$ & $\begin{array}{l}\text { Issues related } \\
\text { to time, } \\
\text { demands of } \\
\text { online } \\
\text { participation, } \\
\text { experiences } \\
\text { of conflict, } \\
\text { development } \\
\text { of skills }\end{array}$ & $\begin{array}{l}\text { Consider pros and } \\
\text { cons of flexible } \\
\text { access to } \\
\text { education, } \\
\text { consider } \\
\text { differences in } \\
\text { expectations and } \\
\text { limits of } \\
\text { electronic media, } \\
\text { online skills } \\
\text { development } \\
\text { should also } \\
\text { address clinical } \\
\text { practice, take into } \\
\text { account the } \\
\text { specific nature of } \\
\text { online } \\
\text { environments }\end{array}$ \\
\hline $\begin{array}{l}\text { Seixas, CA. et } \\
\text { al. (2016) }\end{array}$ & $\begin{array}{l}\text { Assess the } \\
\text { usability of } \\
\text { a virtual } \\
\text { learning } \\
\text { environment } \\
\text { for nursing } \\
\text { students }\end{array}$ & $\begin{array}{l}\text { Distance } \\
\text { education } \\
\text { platform } \\
\text { (Moodle) }\end{array}$ & $\begin{array}{l}\text { Questionnaire, } \\
\text { log records } \\
\text { analysis }\end{array}$ & $\begin{array}{l}\text { Ergonomic } \\
\text { and interface } \\
\text { usability, } \\
\text { country of } \\
\text { origin, } \\
\text { experience in } \\
\text { distance } \\
\text { learning }\end{array}$ & $\begin{array}{l}\text { Consider } \\
\text { variables such as } \\
\text { country of origin, } \\
\text { previous } \\
\text { experience in } \\
\text { distance } \\
\text { education }\end{array}$ \\
\hline
\end{tabular}

The key findings and recommendations generated a list of e-platform requirements that could be classified into nine categories: aim and users, platform structure, educational content and materials, knowledge acquisition and achievement of learning outcomes, communication, interaction and feedback, nursing skills, usability, management, and infrastructural and technological support. 


\section{Aim and users}

All of the platforms and the content that was included addressed nursing students or clinical nurses with the aim to encourage nurses to use evidence in their studies or in clinical practice. These platforms, therefore, addressed a variety of users and levels varying from undergraduates, graduates, clinical nurses, or combinations of these students. On some platforms that were studied, different target groups participated simultaneously. The study of Mclntyre addressed undergraduate as well as graduate nurses [29]. Students' levels are master's degree (MSN), bachelor's or baccalaureate's degree (BSN), or the associate or diploma degree (AND) level [28]. None of the studies in the review involved PhD students. In Kowitlawakul's study, two faculty staff members also were included in the study [27].

Some platforms explicitly addressed clinical nurses for whom different descriptions were used such as clinical nurses [25], registered nurses [26], staff nurses [28], or employed students [24].

It is important to consider whether the platform is accessible to only registered members for which users should login or whether open access is allowed. In some of the studies, access was limited to registered members of a specific learning community. In League's study, the website was only available to employees within the organization [28] whereas, in others, there was open access. In all of the nine studies of Du's systematic review [24], users had open access.

Most of the platforms in the studies allowed one language which could be the users' own language or English. The use of one language - and, if so, which language - or the use of multiple languages and the consequences for the aims of the platform should be considered before developing the platform [25].

\section{Platform structure}

Different types of platform structure were determined in the studies. There were three platforms, one of which was a website, and there were four online nursing programmes. In League's study, the website was called 'Evidence Based Practice and Nursing Research'. In Davidson's study [23], the platform was a gamebased platform. The Distance Education Platform (DEP) in Seixas' study [30] was Moodle, which was also referred to as a Virtual Learning Environment (VLE). All of the platforms or websites were structured in a way to contain distance learning courses or modules, for example, in a series of nursing learning modules called Mooshak [24].

Some of the platforms in the studies of the review included additional structures that enabled content and tools such as forum discussions, webinars about nursing topics, podcasts [29], or teleconferencing [24]. The content can be in text as well as in audio and video formats [24]. These formats may also include audio-visual presentations as well as graphics and animations, usually with multimedia and interactive elements [26]. In game-based learning, visible milestones and badges play a significant role [23].

The structure of the platform should allow access to electronic databases as is mentioned in all of the studies. 


\section{Educational content and materials}

Educational content includes providing direct access to practice-based and evidence-based guidelines [28]. Three studies explicitly explain what educational content concerning nursing research skills is included [23, $27,28]$. This includes expertise in basic research principles and expertise concerning research paradigms such as quantitative and qualitative methods [27] and the major characteristics, strengths, and limitations of quantitative and qualitative research designs [23]. In Gagnon's study [25], expertise in additional research designs is also included. Research skills include developing search strategies that are quest-based in order to formulate clinical questions [23] and, in particular, using the PICO (= Patient, Intervention, Comparison, Outcome) structure $[23,28]$. Subsequent skills include performing these literature search strategies using a variety of library databases $[23,25]$. The literature search begins with having access to library sources and search engines such as Google Scholar or Medline [28]. All of the studies mention that there should be access to and the skills to use electronic databases with scientific nursing publications. After performing the search strategy, additional skills concern the critical appraisal of research reports [23].

Additional research skills that are addressed in the content of learning modules are data analysis, for example, statistics [25] and academic writing [29].

\section{Knowledge acquisition and achievement of learning outcomes}

Knowledge acquisition outcomes were defined in terms of improving research skills or improving the use of EBP. In League's study [28], learning outcomes were the perceived access to EBP and the perceived barriers, ability, or confidence to use it. A significant improvement in perceived confidence and ability to use evidence and an increase in awareness and interest in EBP was identified [28]. Davidson's study [23] demonstrated the need for guaranteeing progression by increasing levels of learning activities.

Progression also depends on the quality of the teaching, which is vital [26] even though the type of learning is self-directed [25]. Therefore, requirements of the e-platform may involve that distance learning courses should include clear learning goals and learning outcomes to support knowledge acquisition by selfdirected learning. Consequently, courses should provide explicit instructions, examples, and assignments.

The specific characteristics of e-learning or online learning were considered thoroughly in all of the studies. Specific consideration should be given to assessments for measuring progression in learning. Specifically in self-directed learning, it is important to distinguish between formative and summative assessments [24]. In testing the achievement of learning outcomes, priority was on formative assessing which corresponds with the typical features of self-directed learning [25]. However, caution must be taken when prioritizing formative assessing because of the value of summative assessments using online exams required for grading.

\section{Communication, interaction, and feedback}


A basic characteristic of learning with a distance education platform is that it should be interactive, and the way a platform is designed is explicitly referred to as an interactive design [24]. All modules or courses that are included in the platform should be interactive [27].

The interactive character of the platform includes interaction between peer students, teachers, and content, which must be maintained at all times [29]. Communication and interaction with instructors is essential and lack of interaction was mentioned as one of the primary weaknesses of online education [26]. In addition, the role of administrators is explicitly indicated [29].

Interaction is aimed at learning outcomes using feedback from tutors and peers. It is mentioned that feedback should be individual-based and prompt or timely [23]. The study of McIntyre [29] was aimed at discussing how peer dynamics influence student learning in an online environment. One disadvantage of online learning might be the loss of the social process of learning, as indicated in Du [24].

Although learning is realized by distance self-directed learning, which is flexible, feedback and interaction are essential. The lack of opportunity for interaction with tutors or other participants is a barrier, according to Gagnon [25]. In Mclntyre's study [29], it is suggested that peers from one geographical area could be connected. Interaction can be realized with a-synchronous as well as synchronous tools, and both tools must be available [29]. It is recommended to anticipate adequate balancing between real-life and online communication. Therefore, it is suggested that the e-platform includes materials for use in classroom settings as well.

\section{Nursing skills}

Apart from learning outcomes concerning nursing research, outcomes also include clinical nursing skills performance which was one of the outcomes in Du's study [24]. All of the authors agree that the acquisition

of research skills should enhance the transfer to clinical practice and, according to League [28], should also increase the access and use of evidence in their clinical nursing profession. Knowledge acquisition is aimed at the transfer of knowledge, that is, the e-platform should enhance nursing skills performance to put acquired knowledge into practice [25]. A further requirement of knowledge transfer could be that knowledge should be disseminated among colleagues [25]. It was suggested that it is important to allocate - extra time for staff to realize knowledge transfer at work [28].

\section{Usability}

In all of the studies, usability was an important feature that involves user friendliness, enhancing student motivation, and engagement [23]. Usability requirements such as easy site navigation and rapid load [25] as well as attractive design and content of the platform were proposed by all of the platform users. In addition, ergonomic usability is needed [30]. 
Another feature of usability is accessibility which may be open, closed, or a mixture of open and closed for certain modules. Usability of the platform should enhance and support flexibility which is the key of distance learning and involves flexibility in time, place, and learning activities [23]. Flexibility for accessing education encourages students to work across time zones [29].

Usability also concerns platform structure and information to users thus requires a clear platform and course information, for example, by curriculum mapping [24] and useful instructions [25]. Information including nursing information and platform contact information should be easy to locate.

Users should be willing to engage and commit themselves to work on it which is connected to the level of independence of the user, the quality of instructions, and the system feedback [30]. One important barrier is inadequate information literacy [24]. Earlier experience in distance education in users is important, however, sometimes this earlier experience is insufficient [30].

\section{Management}

A platform should include management tools for developing and maintaining structures and materials. It must be easy to further develop the platform and to add information. Management requirements involve monitoring tools for student tracking [24] to check the number of logins or the number of users and login security. Some platforms contain a combination of systems, for example, the platform Moodle also includes a teaching and learning management system (LMS) and a course management system (CMS) to facilitate educators in developing online courses or online support [30]. Educators should resist the convenience of pre-established packages [29] as, apparently, the development of new educational materials is highly valuated compared to the use of pre-established packages.

\section{Infrastructural and technological support}

All of the studies demonstrate that, as a primary condition for developing an online platform, access to the Internet should not be restricted in terms of time and place. In addition, there should be no restrictions in costs when access to the internet is concerned [24]. The quality of the effective technological support that is provided is essential [26].

Requirements concerning infrastructural and technological support include that the e-platform can be used from different devices such as a laptop, tablet, or smartphone. In Karaman's study [26], platform users mentioned perceiving problems reaching the call centre. Hardware and software problems often occur [24]. Further requirements to be considered are the unlimited availability of technological support by a support center or helpdesk, at any time, from any place, and at no cost. Testing by information technology personnel is required to check for viruses in the system [27]. All of the studies showed that the technological infrastructure should enable unrestricted access to links to other websites or electronic databases. 


\section{Requirements to be included in the Delphi study}

Most requirements that were identified from the literature review and presented above, were included in the Delphi study. All of the requirements, which were categorized into nine categories, could be incorporated into four groups of statements for the Delphi. The group content-related requirements encompasses 'aim and users', 'educational content and materials', 'nursing skills' and 'platform structure'. The group functional requirements contains 'knowledge acquisition and achievement of learning outcomes', 'communication, interaction and feedback', and 'management'. The group usability requirements covers the category 'usability'. The group technological requirements includes 'infrastructural and technological support'.

\section{Results Delphi study}

\section{Experts' characteristics}

As presented in Table 4, in the first round, 59 respondents completed the online questionnaire including 48 from Kazakhstan (81\%) and 11 from European countries (19\%). Almost half of the group of experts are employed at a university (44\%) and $46 \%$ in a healthcare organization. The respondents' expertise is in nursing practice $(46 \%)$, nursing education (32\%), nursing research $(24 \%)$ and development of e-platforms $(5 \%)$. In the second round, 17 experts completed the questionnaire: 11 from Kazakhstan (65\%) and six from European countries (35\%). In contrast to the first round, most respondents in the second round work at a university.

Table 4: Experts' characteristics 


\begin{tabular}{|c|c|c|c|c|}
\hline \multirow[t]{2}{*}{ Characteristics } & \multicolumn{2}{|c|}{$\begin{array}{l}\text { First round } \\
(N=59)\end{array}$} & \multicolumn{2}{|c|}{$\begin{array}{l}\text { Second round } \\
(\mathrm{N}=17)\end{array}$} \\
\hline & $\mathbf{n}$ & $\%$ & $\mathbf{n}$ & $\%$ \\
\hline \multicolumn{5}{|l|}{ Country } \\
\hline - Kazakhstan & 48 & $81 \%$ & 11 & $65 \%$ \\
\hline - Europe & 11 & $19 \%$ & 6 & $35 \%$ \\
\hline \multicolumn{5}{|l|}{ Work $^{1}$} \\
\hline - University & 26 & $44 \%$ & 13 & $76 \%$ \\
\hline - Health care organization & 27 & $46 \%$ & 2 & $12 \%$ \\
\hline - Other organization & 6 & $10 \%$ & 3 & $18 \%$ \\
\hline - missing value & & & 1 & $6 \%$ \\
\hline \multicolumn{5}{|l|}{ Expertise $^{1}$} \\
\hline - nursing practice & 27 & $46 \%$ & 1 & $6 \%$ \\
\hline - nursing education & 19 & $32 \%$ & 8 & $47 \%$ \\
\hline - nursing research & 14 & $24 \%$ & 6 & $35 \%$ \\
\hline - Development of e-platform & 3 & $5 \%$ & 3 & $18 \%$ \\
\hline - missing value & 1 & $2 \%$ & 1 & $6 \%$ \\
\hline
\end{tabular}

${ }^{1}$ Respondents were able to select more than one option

\section{Essential and useful requirements}

Requirements rated as 'essential' with a cvr of 0.29 and above are presented in Table 5. Requirements rated as 'useful but not essential' with a cvr below 0.29 are presented in Table 6. 
Table 5

Essential requirements

\begin{tabular}{lll}
\hline GROUP & It is ESSENTIAL that the e-platform & cvr agreement \\
Category & first second \\
& round round (n= \\
& $(n=17)^{1}$ \\
& $59)$
\end{tabular}

\section{CONTENT}

Aim and users

enhances

1. to put nursing knowledge into practice

$0.83 \quad 93.75 \%$

2. nursing skills performance

$0.69 \quad 76.47 \%$

3. increasing usability of evidence in clinical nursing professions

$0.47 \quad 87.50 \%$

4. transfer of knowledge to colleagues

$0.46 \quad 81.25 \%$

5. nursing management and leadership

$* * 2 \quad 81.25 \%$

has the following characteristics
6. Information is available in Russian and
$0.63 \quad 100.00 \%$

English and Kazakh

includes for educational purposes

7. materials for different target groups (bachelor, $\quad 0.66 \quad 100.00 \%$ master)

Educational content and includes educational materials about

materials

\begin{tabular}{|lll|}
\hline $\begin{array}{l}\text { 8. evidence based nursing } \\
\begin{array}{l}\text { 9. evidence based nursing clinical guidelines for } \\
\text { use in practice }\end{array}\end{array}$ & 0.90 & $94.12 \%$ \\
\hline $\begin{array}{l}\text { 10. nursing research skills } \\
\text { 11. nursing leadership }\end{array}$ & 0.55 & $100.00 \%$ \\
\hline $\begin{array}{l}\text { includes information concerning nursing } \\
\text { research skills such as }\end{array}$ & 0.42 & $93.75 \%$ \\
\hline \begin{tabular}{l} 
12. To apply evidence in the clinical practice \\
\hline
\end{tabular} & 0.64 & $93.33 \%$ \\
\hline
\end{tabular}

${ }^{1}$ Due to the fact that some questions were not answered by one or two persons, the percentages can differ because percentages are calculated by the number of respondents per question.

$2 * *$ added in the second round based on answers on the open questions in the first round. 


\begin{tabular}{|c|c|c|c|}
\hline \multirow[t]{7}{*}{ Category } & It is ESSENTIAL that the e-platform & $\begin{array}{l}\text { cvr } \\
\text { first } \\
\text { round } \\
(n= \\
59)\end{array}$ & $\begin{array}{l}\text { agreement } \\
\text { second } \\
\text { round }(n= \\
17)^{1}\end{array}$ \\
\hline & 13. Basic research principles & 0.61 & $87.50 \%$ \\
\hline & $\begin{array}{l}\text { 14. Skills to use electronic databases } \\
\text { (information systems in nursing) }\end{array}$ & 0.61 & $87.50 \%$ \\
\hline & 15. Literature searches & 0.44 & $86.67 \%$ \\
\hline & 16. Qualitative designs & 0.36 & $80.00 \%$ \\
\hline & $\begin{array}{l}\text { 17. Formulate quests/ research questions e.g. in } \\
\text { PICO format }\end{array}$ & 0.35 & $86.67 \%$ \\
\hline & $\begin{array}{l}\text { 18. Quantitative designs (including surveys and } \\
\text { cross-sectional designs) }\end{array}$ & 0.32 & $82.35 \%$ \\
\hline \multirow[t]{11}{*}{ Nursing skills } & $\begin{array}{l}\text { includes information concerning nursing topics } \\
\text { such as }\end{array}$ & & \\
\hline & $\begin{array}{l}\text { 19. Patient safety (such as hygiene, prevention } \\
\text { of adverse events) }\end{array}$ & 0.73 & $100.00 \%$ \\
\hline & $\begin{array}{l}\text { 20. Physiological-complex (such as care for } \\
\text { cancer; optimize neurological function) }\end{array}$ & 0.56 & $93.75 \%$ \\
\hline & $\begin{array}{l}\text { 21. Family (such as child baring care and care to } \\
\text { support families) }\end{array}$ & 0.52 & $93.33 \%$ \\
\hline & $\begin{array}{l}\text { 22. Health promotion and prevention of health } \\
\text { risks }\end{array}$ & 0.45 & $93.75 \%$ \\
\hline & $\begin{array}{l}\text { 23. Behavioural (such as dementia and } \\
\text { depression) }\end{array}$ & 0.39 & $93.33 \%$ \\
\hline & 24. Health System & 0.39 & $85.71 \%$ \\
\hline & $\begin{array}{l}\text { 25. Nursing documentation (development and } \\
\text { practical use) }\end{array}$ & ** & $93.33 \%$ \\
\hline & $\begin{array}{l}\text { 26. Quality management (tools, techniques for } \\
\text { improving nursing practice) }\end{array}$ & ** & $93.33 \%$ \\
\hline & $\begin{array}{l}\text { 27. Standard operating procedures (SOP) and } \\
\text { complex routine operations }\end{array}$ & ** & $93.33 \%$ \\
\hline & 28. Laws and regulations for nursing practice & ** & $93.33 \%$ \\
\hline \multicolumn{4}{|c|}{$\begin{array}{l}1 \text { Due to the fact that some questions were not answered by one or two persons, the percentages can } \\
\text { differ because percentages are calculated by the number of respondents per question. }\end{array}$} \\
\hline
\end{tabular}




\begin{tabular}{|c|c|c|c|}
\hline $\begin{array}{l}\text { GROUP } \\
\text { Category }\end{array}$ & It is ESSENTIAL that the e-platform & $\begin{array}{l}\text { cvr } \\
\text { first } \\
\text { round } \\
(n= \\
59)\end{array}$ & $\begin{array}{l}\text { agreement } \\
\text { second } \\
\text { round }(\mathrm{n}= \\
17)^{1}\end{array}$ \\
\hline \multirow[t]{2}{*}{ Platform structure } & \multicolumn{3}{|l|}{ includes } \\
\hline & $\begin{array}{l}\text { 29. an agenda/calendar with relevant nursing } \\
\text { research and nursing educational activities in } \\
\text { Kazakhstan and beyond }\end{array}$ & 0.34 & $\begin{array}{l}\text { missing } \\
\text { value }\end{array}$ \\
\hline \multicolumn{4}{|l|}{ FUNCTIONAL } \\
\hline \multirow{4}{*}{$\begin{array}{l}\text { Communication } \\
\text { interaction and feedback }\end{array}$} & \multicolumn{3}{|l|}{ includes functionalities for } \\
\hline & 30. online collaboration & 0.30 & $81.25 \%$ \\
\hline & \multicolumn{3}{|l|}{ includes distance learning courses which } \\
\hline & $\begin{array}{l}\text { 31. provide timely feedback from tutors and } \\
\text { peers }\end{array}$ & 0.62 & $88.24 \%$ \\
\hline \multirow{10}{*}{$\begin{array}{l}\text { Knowledge acquisition } \\
\text { and achievement of } \\
\text { learning outcomes }\end{array}$} & \multicolumn{3}{|l|}{ includes for educational purposes } \\
\hline & 32. distance learning courses & 0.47 & $100.00 \%$ \\
\hline & 33. instruction films & 0.41 & $93.75 \%$ \\
\hline & \multicolumn{3}{|l|}{ includes distance learning courses which } \\
\hline & $\begin{array}{l}\text { 34. include clear learning goals and learning } \\
\text { outcomes }\end{array}$ & 0.86 & $87.50 \%$ \\
\hline & 35. have a clear structure and a course map & 0.83 & $100.00 \%$ \\
\hline & $\begin{array}{l}\text { 36. include instructions, examples and } \\
\text { assignments }\end{array}$ & 0.73 & $100.00 \%$ \\
\hline & $\begin{array}{l}\text { 37. support knowledge acquisition by enabling } \\
\text { self-directed learning }\end{array}$ & 0.61 & $100.00 \%$ \\
\hline & $\begin{array}{l}\text { 38. include summative assessment with } \\
\text { certification }\end{array}$ & 0.49 & $87.50 \%$ \\
\hline & $\begin{array}{l}\text { 39. include formative assessment to assess } \\
\text { knowledge acquisition }\end{array}$ & 0.40 & $81.25 \%$ \\
\hline Management & \multicolumn{3}{|l|}{ includes tools } \\
\hline
\end{tabular}

${ }^{1}$ Due to the fact that some questions were not answered by one or two persons, the percentages can differ because percentages are calculated by the number of respondents per question.

$2 \star *$ added in the second round based on answers on the open questions in the first round. 


\begin{tabular}{|c|c|c|c|}
\hline \multirow[t]{4}{*}{ Category } & It is ESSENTIAL that the e-platform & $\begin{array}{l}\text { cvr } \\
\text { first } \\
\text { round } \\
(n= \\
59)\end{array}$ & $\begin{array}{l}\text { agreement } \\
\text { second } \\
\text { round }(n= \\
17)^{1}\end{array}$ \\
\hline & $\begin{array}{l}\text { 40. to secure personal data and administration } \\
\text { of courses }\end{array}$ & 0.44 & $93.75 \%$ \\
\hline & 41. to manage user management accounts & 0.40 & $68.75 \%$ \\
\hline & $\begin{array}{l}\text { 42. for content management so it is easy to add } \\
\text { and change information }\end{array}$ & 0.29 & $82.35 \%$ \\
\hline \multicolumn{4}{|l|}{ TECHNICAL } \\
\hline \multirow{4}{*}{$\begin{array}{l}\text { Infrastructural and } \\
\text { technological support }\end{array}$} & \multicolumn{3}{|l|}{ should technically support } \\
\hline & 43. use on a computer, tablet, and mobile phone. & 0.83 & $100.00 \%$ \\
\hline & $\begin{array}{l}\text { 44. guaranteed technological support (not } \\
\text { restricted to time, place, or cost) }\end{array}$ & 0.53 & $87.50 \%$ \\
\hline & 45. use in different browsers & 0.51 & $93.75 \%$ \\
\hline \multicolumn{4}{|l|}{ USABILITY } \\
\hline \multirow[t]{8}{*}{ Usability } & \multicolumn{3}{|l|}{ has the following characteristics } \\
\hline & 46. well designed and attractive & 0.82 & $100.00 \%$ \\
\hline & 47. open and free access to information & 0.80 & $100.00 \%$ \\
\hline & 48. clear and simple site navigation & 0.75 & $100.00 \%$ \\
\hline & $\begin{array}{l}\text { 49. text on each page is not too much and easy } \\
\text { to read }\end{array}$ & 0.62 & $81.25 \%$ \\
\hline & 50. contact information is easy to be found & 0.58 & $100.00 \%$ \\
\hline & $\begin{array}{l}\text { 51. login for educational and collaboration } \\
\text { purposes }\end{array}$ & 0.44 & $93.75 \%$ \\
\hline & 52. clear site structure & ** & $100.00 \%$ \\
\hline \multicolumn{4}{|c|}{$\begin{array}{l}1 \text { Due to the fact that some questions were not answered by one or two persons, the percentages can } \\
\text { differ because percentages are calculated by the number of respondents per question. }\end{array}$} \\
\hline
\end{tabular}


Useful but not essential requirements

\begin{tabular}{|c|c|c|c|}
\hline $\begin{array}{l}\text { GROUP } \\
\text { Category }\end{array}$ & It is USEFUL BUT NOT ESSENTIAL that the e-platform & $\begin{array}{l}\text { cvr } \\
\text { first } \\
\text { round } \\
(n= \\
59)\end{array}$ & $\begin{array}{l}\text { agreement } \\
\text { second } \\
\text { round }(n= \\
17)^{1}\end{array}$ \\
\hline \multicolumn{4}{|l|}{ CONTENT } \\
\hline \multirow[t]{8}{*}{ Platform structure } & includes & & \\
\hline & 1. webinars about nursing topics & 0.28 & $75.00 \%$ \\
\hline & $\begin{array}{l}\text { 2. a blog about several nursing topics, updated once a } \\
\text { month }\end{array}$ & 0.22 & $82.35 \%$ \\
\hline & $\begin{array}{l}\text { 3. links to electronic databases with scientific nursing } \\
\text { publications }\end{array}$ & 0.14 & $86.67 \%$ \\
\hline & 4. forum discussions for nurses on nursing topics & 0.07 & $93.75 \%$ \\
\hline & $\begin{array}{l}\text { 5. links to international websites with additional nursing } \\
\text { guidelines }\end{array}$ & 0.07 & $73.33 \%$ \\
\hline & $\begin{array}{l}\text { 6. an overview of important stakeholders for nursing in } \\
\text { Kazakhstan such as universities with bachelor and/or } \\
\text { master programmes in nursing, university medical } \\
\text { hospitals }\end{array}$ & 0.00 & $81.25 \%$ \\
\hline & $\begin{array}{l}\text { 7. an overview of national and international institutions } \\
\text { working together with the } \mathrm{CNE}\end{array}$ & -0.09 & $87.50 \%$ \\
\hline \multirow[t]{2}{*}{ Nursing skills } & include information concerning nursing topics such as & & \\
\hline & $\begin{array}{l}\text { 8. Physiological-basic (such as physical activity, nutrition } \\
\text { support) }\end{array}$ & 0.19 & $53.33 \%$ \\
\hline \multirow{4}{*}{$\begin{array}{l}\text { Educational } \\
\text { content and } \\
\text { materials }\end{array}$} & $\begin{array}{l}\text { includes information concerning nursing research skills } \\
\text { such as }\end{array}$ & & \\
\hline & 9. Analysis, such as statistics or qualitative analysis & 0.16 & $73.33 \%$ \\
\hline & 10. Critical appraisal of scientific literature & 0.04 & $80.00 \%$ \\
\hline & 11. Academic writing & -0.05 & $81.25 \%$ \\
\hline \multicolumn{4}{|l|}{ FUNCTIONAL } \\
\hline \multirow{2}{*}{$\begin{array}{l}\text { Communication } \\
\text { interaction and } \\
\text { feedback }\end{array}$} & includes functionalities for & & \\
\hline & 12. online discussions & 0.11 & $80.00 \%$ \\
\hline
\end{tabular}

${ }^{1}$ Due to some missing values percentages may deviate 


\begin{tabular}{|c|c|c|c|}
\hline $\begin{array}{l}\text { GROUP } \\
\text { Category }\end{array}$ & It is USEFUL BUT NOT ESSENTIAL that the e-platform & $\begin{array}{l}\text { cvr } \\
\text { first } \\
\text { round } \\
(n= \\
59)\end{array}$ & $\begin{array}{l}\text { agreement } \\
\text { second } \\
\text { round }(\mathrm{n}= \\
17)^{1}\end{array}$ \\
\hline & \multicolumn{3}{|l|}{ includes distance learning courses which } \\
\hline & $\begin{array}{l}\text { 13. enable communication and interaction with tutors } \\
\text { and peer students }\end{array}$ & 0.05 & $88.24 \%$ \\
\hline \multirow{2}{*}{$\begin{array}{l}\text { Knowledge } \\
\text { acquisition and } \\
\text { achievement of } \\
\text { learning outcomes }\end{array}$} & \multicolumn{3}{|l|}{ includes for educational purposes } \\
\hline & $\begin{array}{l}\text { 14. educational materials for use in classroom settings } \\
\text { to download }\end{array}$ & 0.28 & $81.25 \%$ \\
\hline \multirow[t]{2}{*}{ Management } & \multicolumn{3}{|l|}{ includes tools } \\
\hline & $\begin{array}{l}\text { 15. to report functions with the option to monitor the } \\
\text { number of users, popularity of the different items, and } \\
\text { improve the site content }\end{array}$ & 0.00 & $81.25 \%$ \\
\hline
\end{tabular}

\section{Four groups of requirements}

The four groups including the essential and useful requirements are presented below.

\section{Content related requirements}

\section{Aim and users}

Regarding the aim of the e-platform, it is considered to be essential that the e-platform enhances nursing skills performance, the transfer of knowledge into practice and to colleagues, and increasing usability of evidence in clinical nursing. Resulting from the open questioning, 'enhancing nursing management and leadership' was added as being an essential requirement, which was confirmed in the second round. Concerning users, it is vitally important that information is available in Russian and English as well as in Kazakh. For educational purposes, it is absolutely necessary that the e-platform includes materials for different target groups such as bachelor's and master's students. No requirements concerning aim and users were rated as useful but not essential.

\section{Educational content and materials}

It is considered essential that the e-platform includes educational materials about evidence-based nursing, nursing clinical guidelines, nursing research skills, and nursing leadership. It is also very important to include information about nursing research skills such as the application of evidence in clinical practice, 
basic research principles, skills to use electronic databases, literature searches, qualitative and quantitative designs, and the formulation of research questions.

Advanced research skills such as statistics or qualitative analysis, critical appraisal of scientific literature, and academic writing were rated as useful but not essential.

\section{Nursing skills}

Concerning the nursing topics obtained from the seven NIC domains, six of these were rated as essential. These are: patient safety, physiological-complex, family, health promotion, behavioral, and health system. The domain physiological-basic was rated as useful but not essential, although no agreement was achieved in the second round.

With open questioning, experts added statements concerning nursing documentation, quality management, standard operating procedures, and laws and regulations. These additional requirements were rated as essential in the second round, which was confirmed by high levels of agreement.

\section{Platform structure}

It is indispensable that the e-platform includes an agenda/calendar with relevant nursing research and educational activities in Kazakhstan and beyond.

Other requirements related to platform structure are useful but not essential. These are - with decreasing cvr values - webinars about nursing topics, a blog about several nursing topics, links to electronic databases with scientific nursing publications, forum discussions on nursing topics, links to international websites with additional nursing guidelines, an overview of important stakeholders for nursing in Kazakhstan such as universities with bachelor or master programmes in nursing or university medical hospitals, and an overview of national and international institutions working together with the CNE.

\section{Functional requirements}

\section{Communication, interaction and feedback}

Online collaboration was rated as an essential requirement for the e-platform whereas online discussions are perceived useful but not essential. It is very important that each distance learning course provides timely feedback from tutors and peers, and it is considered useful that distance learning courses enable communication and interaction with tutors and peer students.

\section{Knowledge acquisition and achievement of learning outcomes}

For educational purposes, it is essential that the e-platform includes distance learning courses and instruction films. Educational materials to download for use in classroom settings are perceived useful but not essential. For knowledge acquisition and achievement of learning outcomes, it is essential that 
distance learning courses include clear learning goals and learning outcomes, have a clear structure and a course map, include instructions, examples, and assignments, support knowledge acquisition by enabling self-directed learning, include summative assessment with certification, and include a formative assessment to assess knowledge acquisition.

\section{Management}

It is an essential requirement that the e-platform includes tools to secure personal data and administration of courses, to manage user management accounts, and to include tools for content management to add and change information. It is useful but not essential to include tools to report and monitor the number of users and popularity of the different items of the e-platform.

\section{Technical requirements}

\section{Infrastructural and technological support}

All technical requirements are rated as essential. With high levels of agreement, it is perceived essential that e-platform technically supports the use of a computer, tablet, and mobile phone, use in different browsers, and that technological support (not restricted to time, place, or cost) is guaranteed.

\section{Usability requirements}

\section{Usability}

All usability requirements are perceived as essential. The usability characteristics refer to proper and attractive design, open and free access to information, clear and simple site navigation, text on each page is not too much and easy to read, contact information is easily found, login for educational and collaboration purposes, and a clear site structure.

\section{Discussion}

The aim of this research was to identify and prioritize requirements for an e-platform in order to strengthen nursing in Kazakhstan. The literature review generated nine categories of requirements that were incorporated into four groups for the Delphi study. The two-step research design that included literature review findings to be validated by experts' opinions concerning the Kazakh context generated a valid list of 52 essential and 15 useful requirements with a high level of consensus. Apparently, the input for the Delphi study that derived from the literature and from other project activities was relevant and corresponded to the perceptions of experts concerning the needs of future users of the e-platform to be developed.

\section{Identifying and prioritizing requirements}


The essential and useful requirements are among all four groups that cover the nine categories generated from the literature review. Although some requirements could be placed into more than one category or group, the researchers achieved consensus after further examination. The analysis of Delphi outcomes generated insight in the meaning and relevance of the requirements particularly in cases of deviance such as when there is overlap. The requirement 'provide timely feedback from tutors and peers', for example, was categorized in the category 'communication, interaction and feedback' but also in 'knowledge acquisition and achievement of learning outcomes'. Both categories were covered by the same Delphi group after all, that is, functional, in which most requirements were rated as essential. The literature confirms that most learning management systems offer functionalities for communication, interaction, and feedback which, if applicated appropriately, contribute significantly to knowledge acquisition and achievement of learning outcomes $[25,26,29]$.

Almost all of the content-related requirements in the categories 'aims and users', 'educational content and materials', and 'nursing skills' were considered essential. Within the category 'educational content and materials', the basic research skills were rated as essential whereas the advanced research skills were rated as useful but not essential. Basic research skills are skills such as applying evidence in the nursing practice and using electronic databases. Advanced research skills refer to analysing methods, critical appraisal of scientific literature, and academic writing. An explanation for the differences in the rating of basic and advanced skills could be that - although there are nursing professionals at a master level among the future users of the e-platform [14] - nursing research developments are quite recent in Kazakhstan and, therefore, research skills at an advanced level are not a priority.

The accurate examination of categories and groups show that requirements concerning platform structure are useful but not essential, apart from one requirement, that is, 'an agenda or calendar with relevant nursing research and nursing educational activities in Kazakhstan and beyond' which was considered an essential requirement. Although this requirement was not obtained from the literature review but from other project activities [14], it was included into the Delphi and was rated as essential. Apparently, the experts anticipated that platform users would appreciate being well-informed concerning nursing research and education activities. Although this requirement had not been included in the second round of the Delphi, it could be a topic of interest to consult with future users when developing an e-platform.

The contribution of this study is that including the future users' perceptions was reinforced by inviting experts to add more statements. This resulted in five additional essential content-related requirements for the Delphi and thus contributed to the embedding of results in the experts' perspectives. In the first round, for example, experts added that the e-platform should enhance nursing leadership. This input was relevant since nursing leadership is considered to be a key factor in implementing evidence-based nursing [31].

\section{Methods used}

The two-step research design, which is also applied in other health related-studies [17], appeared to be an appropriate method for identifying and prioritizing requirements for an e-platform in nursing. The 
requirements ascertained in the literature are validated for the specific context using the Delphi method. The Delphi method is widely employed for achieving consensus among a group of experts, although there is a wide variety in how Delphi studies are conducted and ratings are analysed [21].

A strength of the Delphi was the diverse composition of the panel with experts from Kazakhstan and from European countries with a majority of Kazakh respondents. Consequently, the results represent Kazakh users' perceptions and, therefore, are well-embedded in the national context. At the same time, limitations of this approach are that the panel composition varied from experienced e-platform users to non-users whereas the results from the literature review were derived from samples of study participants who had recently practised using an e-platform and were thus all experienced platform users.

A limitation is the low response rate in the second round of the Delphi with only 17 respondents compared to 59 respondents in the first round. This low rate in the second round also coincides with a high percentage of panel experts employed at universities, which was $76 \%$ in the second round in contrast to $44 \%$ in the first round.

In this study, the cvr was used to analyse ratings in the first round, and frequencies were utilized in the second round applying a consensus threshold of $75 \%$. A strength of this combined analysis technique is that it enables providing feedback and adjusting scores by the panel members in the course of the study. A limitation of the technique is that no explicit criteria for removing items from the list of requirements were determined and that the number of Delphi rounds was established beforehand. Consequently, no consensus was achieved for three requirements in the list of not essential but useful. Although this limitation appears in most Delphi studies, according to [21], it is recommended to prevent this when constructing a Delphi study.

Beyond the scope of this study is the organisational structure monitoring the e-platform. In this study, consulting the future users and different stakeholders was realised in the context of an international project, and the organisational structure was guaranteed by the CNE in Kazakhstan. Once the platform is fully operational, the project might be accomplished, and the support from international stakeholders will probably be reduced. In general, to guarantee that an e-platform will be successful for the long-term, it is important to determine the responsibilities concerning monitoring the content, the functionality, the usability, and the technology.

\section{Implications for practice and research}

To strengthen nursing in Kazakhstan, the e-platform to be developed should correspond the list of essential and useful requirements found in the study. During the development process of the e-platform, the authors recommend including experts and future users regularly for testing in order to guarantee that the e-platform accords with the users' needs.

The list of 52 essential and 15 useful requirements is context-bound but may also be applicable as a reference framework when prioritizing requirements for the development of other e-platforms in the trinity 
of nursing education, nursing research, and nursing practice.

The nine categories and four groups of requirements can be used as a starting point and elaborated. The two-step approach is recommended to achieve consensus on determining and prioritizing the essential and useful requirements. It is recommended to always consult a panel of experts including internal and external stakeholders as this generates valid results that represent experienced and future users' perceptions and are well-embedded in the specific context.

Further research is recommended to determine how the e-platform that is developed will contribute to improving nursing in Kazakhstan by increasing knowledge sharing and collaboration in the trinity of nursing education, nursing research, and nursing practice. Since ICT developments and use of ICT is increasing rapidly, it is necessary to keep research up to date and consider how these developments affect knowledge sharing and collaboration in the field of nursing on national and international levels.

\section{Conclusion}

For the development of an e-platform to strengthen nursing in Kazakhstan, 52 essential and 15 useful requirements have been identified and prioritized, with a high level of consensus. The e-platform, developed according to this list of requirements, is expected to contribute to the improvement of nursing education, nursing research, and nursing practice in Kazakhstan. Most content-related requirements are essential, although some advanced research skills are useful but not essential. In addition, most functional, usability, and technical requirements are essential. The results of a literature review and additional statements from other sources such as project activities generated the appropriate input for achieving consensus on identifying and prioritizing requirements. The list of requirements found in this study is context-bound but may also be applicable as a reference framework when prioritizing requirements for the development of other e-platforms in the trinity of nursing education, nursing research, and nursing practice.

\section{Abbreviations}

AND Associate Nursing Degree

BSN Bachelor's Nursing Degree

CMS Course Management System

CNE Center of Nursing Excellence

CVR Content validity ratio

DEP Distance Education Platform

EBP Evidence Based Practice

HEI Higher Educational Institute 
ICT Information and communication technology

LMS Learning Management System

MSN Master's Nursing Degree

NIC Nursing Intervention Classification

PICO Patient, Intervention, Comparison, Outcome

ProlnCa Promoting the Innovation Capacity of Higher Education in Nursing During Health Services' Transition

SDLR Self Directed Learning Readiness

SDLRSNE Self Directed Learning Readiness Scale for Nursing Education

VLE Virtual Learning Environment

\section{Declarations}

\section{Acknowledgements}

The authors thank Gulim Aimagambetova for her assistance with the online questionnaires and EnglishRussian translations. We thank Jari Hautamaki for contributing to the literature search. Thanks also go to the ProlnCa project members and the respondents of the Delphi questionnaire for their contribution.

The research is conducted as a part of the ProlnCa project. This project has been funded with support from the European Commission. This publication reflects the views only of the author, and the Commission cannot be held responsible for any use which may be made of the information contained therein.

\section{Availability of data and materials}

The datasets used and analyzed during the present study are available from the corresponding author on reasonable request.

\section{Additional information}

\section{Competing interests}

The authors declare that they have no competing interests.

\section{Contribution of the authors}

BLD and WP: Initiation and design of the research. ATO conducting the literature review with input from AA and WP. BLD, WP and AA developing the Delphi questionnaires and AA collecting the data. BLD and ATO 
data analysis and writing the paper. WP Editorial revision of paper. All authors read and approved the final manuscript.

\section{Ethics declaration}

Ethical approval was not necessary for this study. Participant anonymity was maintained throughout both rounds of the Delphi study.

\section{References}

1] Frisch NC, Borycki EM, Mickelson G, Atherton P, Novak-Lauscher H, Hooker D, Ho K. Use of social media and web 2.0 technologies to increase knowledge and skills of British Columbia nurses. InNI 2012: 11th International Congress on Nursing Informatics, June 23-27, 2012, Montreal, Canada. (Vol. 2012). American Medical Informatics Association.

2] Stevens KR. The impact of evidence-based practice in nursing and the next big ideas. Online $\mathrm{J}$ Issues Nurs. 2013 May 31;18(2):4.

3] Neimann T, Wang VX. Harnessing the Tiger of Emerging E-Learning Platforms. In: Handbook of Research on Program Development and Assessment Methodologies in K-20 Education 2018 (pp. 147-170). IGI Global.

4] Du Z, Fu X, Zhao C, Liu Q, Liu T. Interactive and collaborative e-learning platform with integrated social software and learning management system. In: Proceedings of the 2012 International Conference on Information Technology and Software Engineering 2013 (pp. 11-18). Springer, Berlin, Heidelberg.

5] Ulrich CM, Wallen GR, Cui N, Chittams J, Sweet M, Plemmons D. Establishing good collaborative research practices in the responsible conduct of research in nursing science. Nursing outlook. 2015 Mar 1;63(2):17180 .

6] Weng YH, Kuo KN, Yang CY, Lo HL, Shih YH, Chen C, Chiu YW. Increasing utilization of Internet-based resources following efforts to promote evidence-based medicine: a national study in Taiwan. BMC medical informatics and decision making. 2013 Dec;13(1):4.

7] Weng YH, Kuo KN, Yang CY, Lo HL, Shih YH, Chiu YW. Information-searching behaviors of main and allied health professionals: a nationwide survey in Taiwan. Journal of evaluation in clinical practice. 2013 Oct; 19(5):902-8.

8] Ahmad MM, Musallam R, Allah AH. Nurses and internet health-related information: review on access and utility. Clujul Medical. 2018 Jul; 91(3):266.

9] Bassell K. Social media and the implications for nursing faculty mentoring: A review of the literature. Teaching and Learning in Nursing. 2010; 5:143-8. 
10] Billings DM, Kowalski K, Briston T. Twitter: Consider the use for continuing nursing education. J Continuing Ed in Nursing. 2010; 41,5:199-200.

11] Katsaga A, Kulzhanov M, Karanikolos M, Rechel B. Kazakhkstan health system review. Health systems in transition. 2012; 14(4):1-54.

12] Heikkila J, Hopia H, Hasselberg J, Tiittanen H, Biaghorzina Z. A cross sectional study of nurses' and nurse educators' perceptions of evidence-based practice in Kazakhstan. Annals of Nursing Research and Practice. 2017; 2(1):1016.

13] Nurakhova AD, Heikkilä J, Ospanova DA. Importance of developing the image of the nursing profession in Kazakhstan. Наука и здравоохранение. [Science and Healthcare] 2019; 1.

14] ProlnCa. Promoting the Innovation Capacity of Higher Education in Nursing during Health Services Transition (ProlnCa). Projectplan. 2017. Retrieved: https://www.proinca-nursing.kz.

15] Oxford Centre for Evidence-based Medicine (OCEBM) Levels of Evidence Working Group, 2011. The Oxford 2011 Levels of Evidence.

16] Joanna Briggs Institute (JBI), 2018. Critical Appraisal Tools. Retrieved: joannabriggs.org/jbiapproach.html, 2018.

17] Fleuren $M$, Wiefferink $K$, Paulussen $T$. Determinants of innovation within health care organizations: Literature review and Delphi study. International Journal for Quality in Health Care. 2004; 16 (2): 107-123.

18] Butcher HK, Bulechek GM, Dochterman JMM, Wagner CM. Nursing Interventions classification (NIC)-EBook.2018; Elsevier Health Sciences.

[19] SurveyMonkey. Retrieved 2018: https://nl.surveymonkey.com.

20] Lawshe $\mathrm{CH}$. A quantitative approach to content validity. Personnel psychology. $1975 ; 28,563-575$.

21] Linstone HA, Turoff M. (Eds.). The delphi method. 1975; pp. 3-12. Reading, MA: Addison-Wesley.

22] Diamond IR, Grant RC, Feldman BM, Pencharz PB, Lin, SC, Moore AM, Wales, PW. Defining consensus: a systematic review recommends methodologic criteria for reporting of Delphi studies. Journal of clinical epidemiology. 2014; 67(4), 401-409.

23] Davidson SJ, Cand, L. Teaching EBP Using Game-Based Learning: Improving the Student Experience. Worldviews on Evidence-Based Nursing, 2016; 13:4, 285-293.

24] Du S, Liu Z, Liu S, Yin H, Xu G, Zhang H, Wang A. Web-based distance learning for nurse education: a systematic review. International Nursing Review, 2013; 60, 167-177.

25] Gagnon J, Gagnon MP, Buteau RA, Azizah GM, Jette S, Lampron A, Simonyan D, Asua J, Reviriego E. Adaptation and Evaluation of Online Self-learning Modules to Teach Critical Appraisal and Evidence-Based 
Practice in nursing. Computers, Informatics, Nursing, 2015; 7, 285-294.

26] Karaman S, Kucuk S, Aydemir M. Evaluation of an online continuing education program from the perspective of new graduate nurses. Nurse Education Today, 2014; 34, 836-841.

27] Kowitlawakul Y, Chan MF, Tan SSL, Soong, ASK, Chan SWC. Development of an e-Learning Research Module Using Multimedia Instruction Approach. Computers, Informatics, Nursing, 2017; 3, 158-166.

28] League K, Christenbery T, Sandlin V, Arnow D, Moss K, Wells, N. Increasing Nurses' Access to Evidence Through a Web-Based Resource. Journal of Nursing Administration, 2012; 42:11, 531-535.

29] McIntyre M, McDonald C. A critical Analysis of Online Nursing Education: Balancing Optimistic and Cautionary Perspectives. Canadian Journal of Nursing Research, 2013; 45:1, 36-53.

30] Seixas CA, de Godoy S, Martins JCA, Mazzo A, Baptista RCN, Mendes IAC. Usability Assessment of Moodle by Brazilian and Portuguese Nursing Students. Computer, Informatics, Nursing, 2016; 6, 266-271.

31] Sandström B, Borglin G, Nilsson R, Willman A. Promoting the implementation of evidence-based practice: A literature review focusing on the role of nursing leadership. Worldviews on Evidence-Based Nursing. 2011 Dec; 8(4):212-23.

\section{Figures}




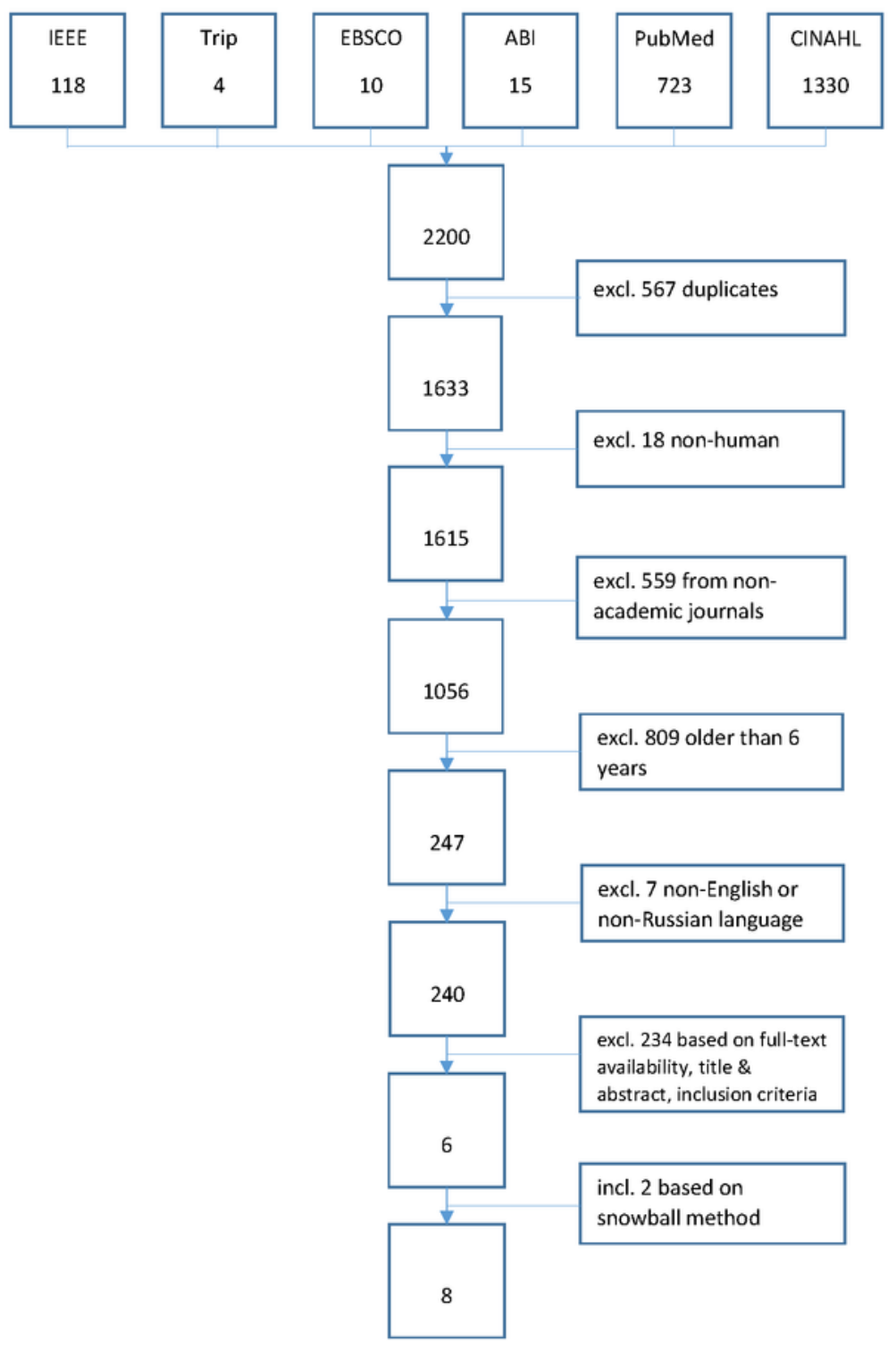

Figure 1

Flowchart 